Наносистели, нанолатеріали, нанотехнології Nanosistemi, Nanomateriali, Nanotehnologii 2020, т. 18, № 4, сc. 939-951
(C) 2020 ІМФ (Інститут металофізики ім. Г. В. Курдюмова НАН України) Надруковано в Україні. Фотокопіювання дозволено тільки відповідно до ліцензі

PACS numbers: 61.05.cp, 61.46.Df, 68.37.Hk, 68.37.Lp, 68.37.Og, 75.50.Tt, 78.30.-j

\title{
Structural and Morphological Analysis of Copper-Doped Magnesium-Nickel Ferrite Nanoparticles
}

\author{
G. A. Osamong ${ }^{1}$, P. K. Kamweru ${ }^{1}$, J. M. Gichumbi ${ }^{1}$, W. K. Ngetich ${ }^{2}$, \\ and F. G. Ndiritu ${ }^{1}$
}

\author{
${ }^{1}$ Department of Physical Sciences, \\ Chuka University, \\ 109-60400 Chuka, Kenya \\ ${ }^{2}$ University of Kwa Zulu Natal, \\ 4041 Durban, South Africa
}

Nanoferrites are materials with the main element being iron and with, at least, one dimension less than $100 \mathrm{~nm}$. They have superior magnetic, electronic, structural, morphological, and optical properties. These properties are ideal for electronic data devices' fabrication among other application areas. The properties could be further tuned by doping with either trivalent or divalent elements. It is hypothesized based on existing literature that the capacities of ferrites could be stretched further to suit the application at hand by introducing dopant cations, change of method of applications that change the cation distribution in the tetrahedral or octahedral sites of the spinel cubic structure of ferrites. Consequently, the search for a perfect nanoferrite for application in electronics and for other applications continues. In this work, copper-doped magnesium-nickel ferrite nanoparticles with composition $\mathrm{Cu}_{x} \mathrm{Mg}_{1-x} \mathrm{NiFe}_{2} \mathrm{O}_{4}$ $(x=0.00,0.15,0.30,0.45,0.60,0.75,1.00)$ are prepared using autocombustion technique, using citric acid as a chelating agent with a maintained $\mathrm{pH}$ of 7, and calcined at $700^{\circ} \mathrm{C}$. Elemental analysis confirmed the expected stoichiometry of the samples. The resulting powders were characterized by infrared spectroscopy (IR), Fourier transform infrared (FTIR), x-ray diffraction (XRD) techniques, and the morphology was determined by transmission electron microscopy (TEM) and scanning electron microscopy (SEM). The XRD patterns of the samples show spinel cubic type of structure, depicted by the signature intense peaks at Miller indices (311) with the lattice parameter varying slightly with copper concentration and crystallite sizes in the range of 4.1-35.58 nm. FTIR showed dominant bonds between $400-499 \mathrm{~cm}^{-1}$ and $500-$ $599 \mathrm{~cm}^{-1}$ as characteristic of a spinel ferrite. Morphological studies by highresolution electron microscopy and scanning electron microscopy showed spherical nature of the samples, and particle size range between $16 \mathrm{~nm}$ and 45 $\mathrm{nm}$ as determined by ImageJ software. The data show that the synthesized ferrite $\mathrm{Cu}_{x} \mathrm{Mg}_{1_{-}-} \mathrm{NiFe}_{2} \mathrm{O}_{4}$ could be applied in memory and electronic storage 
devices as well as in high-density recording media.

Наноферити - це матеріяли, основним елементом яких є Ферум і з, принаймні, одним розміром менше 100 нм. Вони мають чудові магнетні, електронні, структурні, морфологічні й оптичні властивості. Ці властивості ідеально підходять для виготовлення електронних пристроїв даних серед інших областей застосування. Властивості можуть бути додатково налаштовані легуванням з тривалентними або двовалентними елементами. На основі наявної літератури гіпотеза про те, що можливості феритів можуть бути розтягнуті далі, щоб відповідати підручному застосуванню, введенням легувальних катіонів, зміною способу застосувань, що змінюють розподіл катіонів у тетраедричних або октаедричних позиціях шпінельної кубічної структури феритів. Отже, пошук ідеального нанофериту для застосування в електроніці та для інших використань триває. У цій роботі леговані Купрумом магнієво-ніклеві феритові наночастинки зі складом $\mathrm{Cu}_{x} \mathrm{Mg}_{1-x} \mathrm{NiFe}_{2} \mathrm{O}_{4}(x=0.00,0.15,0.30,0.45,0.60,0.75,1.00)$ готуються з використанням техніки автозгоряння, використовуючи лимонну кислоту як засіб гелатування зі збереженим $\mathrm{pH} 7$, і є кальциновані при $700^{\circ} \mathrm{C}$. Елементна аналіза підтвердила очікувану стехіометрію зразків. Одержані порошки характеризувалися інфрачервоною спектроскопією (ІЧ), інфрачервоною спектроскопією з Фур'є-перетвором (ФПІЧ), рентгенівською дифракцією (РД), а морфологію було визначено просвітлювальною електронною мікроскопією (ПЕМ) і сканувальною електронною мікроскопією (CEM). РД-картини зразків показують шпінельний кубічний тип структури, зображений підписом інтенсивних піків при Міллерових індексах (311), з параметром гратниці, що незначно змінюється з концентрацією Купруму та кристалічними розмірами в діяпазоні 4,1-35,58 нм. ФПІЧспектроскопія показала домінувальні зв'язки між 400-499 см${ }^{-1}$ і 500-599 $\mathrm{cm}^{-1}$ як характерні для шпінельного фериту. Морфологічні дослідження електронною мікроскопією з високою роздільчою здатністю та сканувальною електронною мікроскопією показали сферичну природу зразків, а розмір частинок коливається від 16 нм до 45 нм, як визначено програмним забезпеченням ImageJ. Дані показують, що синтезований ферит $\mathrm{Cu}_{x} \mathrm{Mg}_{1-x} \mathrm{NiFe}_{2} \mathrm{O}_{4}$ може бути застосований у запам' ятовувальних та електронних пристроях зберігання даних, а також у носіях запису високої щільності.

Key words: spinel ferrite, nanoparticles, structure, doping, morphology.

Ключові слова: шпінелевий ферит, наночастинки, структура, легування, морфологія.

(Received 31 March, 2020; in revised version, 1 April, 2020)

\section{INTRODUCTION}

Nanotechnology has experienced substantial development and creates materials with enormous potential to change society. Nanomaterials are those with one of their dimensions less than $100 \mathrm{~nm}$ and show 
unique characteristics when compared to the bulk, mostly due to the high surface area to volume ratio [1]. Among the most promising nanomaterials are nanoferrites, which are materials containing iron oxide as the major constituent. They have the general formula $M \mathrm{Fe}_{2} \mathrm{O}_{4}$ where $M$ can be occupied by one two or three different types of cations, be they trivalent or divalent and the cations can be placed in either octahedral and/or tetrahedral sites of the ferrites [2]. By changing the cation occupancy, the properties of ferrites change [3], and this is desirable as it gives the ability to tune ferrite properties.

The preference of cation distribution depends on ionic radius and electronic configuration [4]. Considering this distribution, spinel ferrites can be categorized into two varieties: inverse and normal spinel ferrites and an intermediate state between the normal and inverse structures. For example, nickel ferrite has an inverse spinel structure, which may exhibit a mixed spinel structure when its grain size is reduced to nanometer range [5]. Copper ferrite is mostly also an inverse spinel with tetragonal structure that changes to cubic symmetry at high temperatures, and it has been shown computationally that both normal and inverse structures of copper ferrite may be half metallic [6]. Magnesium ferrite is a pertinent magnetic material showing inverse spinel structure for wide applications owing to its high resistivity, high Curie temperature and environmental stability [7, 8].

Nanoparticles of copper, nickel and magnesium spinel ferrite, possess superior structural and morphological properties [9], which have application in technology such as in storage devices, ferrofluids, memory devices, sensors recording devices [10,11]. Remarkably, these properties are influenced and can be adjusted through composition, method of preparation, $\mathrm{pH}$ and cation distribution in the tetrahedral and octahedral sites [12]. However, the search for a novel ferrite continues for applications in electronic industry through doping [13] to change cations and their distribution, and change of the method of synthesis. Several methods such as ceramic, emulsion, sol-gel, co-precipitation, hydrothermal and combustion methods [14] have been used in the synthesis of ferrites. The Citra gel autocombustion method has good stoichiometric control and allows production of ultrafine nanoparticles in nanorange at relatively low temperature [15]. Sol-gel synthesis method products are of good chemical homogeneity and of high purity [16].

This work reports on the synthesis of the ferrite $\mathrm{Cu}_{x} \mathrm{Mg}_{1-x} \mathrm{NiFe}_{2} \mathrm{O}_{4}$ by substitution of copper in magnesium nickel ferrite with a fixed nickel proportion. This work is aimed at investigation of nanostructure and morphology of copper-doped magnesium-nickel ferrite nanoparticles at a varied doping ratio but same method of preparation. The method of synthesis was Citra gel autocombustion method. The structural and morphological properties as well as elemental composition were studied using XRD, FTIR, SEM, TEM, and XRF, respectively. 


\section{EXPERIMENTAL PROCEDURE}

\subsection{Preparation}

The Citra gel autocombustion method was used to synthesize the doped ferrite. The required stoichiometry of nickel nitrate hexahydrate $\left(\mathrm{Ni}\left(\mathrm{NO}_{3}\right)_{2} \cdot 6 \mathrm{H}_{2} \mathrm{O}\right)$, copper nitrate trihydrate $\left(\mathrm{Cu}\left(\mathrm{NO}_{3}\right)_{2} \cdot 3 \mathrm{H}_{2} \mathrm{O}\right.$, ferric nanohydrate $\left(\mathrm{Fe}\left(\mathrm{NO}_{3}\right)_{3} \cdot 9 \mathrm{H}_{2} \mathrm{O}\right)$, magnesium nitrate hexahydrate $\left(\mathrm{Mg}\left(\mathrm{NO}_{3}\right)_{2} \cdot 6 \mathrm{H}_{2} \mathrm{O}\right)$ based on their molecular weights were dissolved in pure water under magnetic stirring for 30 minutes to get a homogeneous solution. $3 M$ solution citric acid $\left(\mathrm{C}_{6} \mathrm{H}_{8} \mathrm{O}_{7} \cdot \mathrm{H}_{2} \mathrm{O}\right)$ was added to the solution containing metal nitrate solution. Ammonia hydroxide was added to maintain $\mathrm{pH}$ at around 7. The temperature of the resultant mixture was raised to $90^{\circ} \mathrm{C}$ and stirred continuously for $3 \mathrm{~h}$ to form a viscous gel. The gel was heated up to $100^{\circ} \mathrm{C}$ until it gave out brown fumes and eventually autocombusts to form loose powders. The powdered sample was then calcined in a furnace at $700^{\circ} \mathrm{C}$ for $5 \mathrm{~h}$ to remove organic materials as done by Rosnan et al. in 2016 [3]. The calcined sample were then ground to obtain the final $\mathrm{Cu}_{x} \mathrm{Mg}_{1-x} \mathrm{NiFe}_{2} \mathrm{O}_{4}$ with $(x=0.00$, $0.15,0.30,0.45,0.60,0.75,1.00)$ samples.

\subsection{Characterization}

The XRD analysis of the synthesized nanoparticles was done by a powder XRD (Bruker D2 Phaser Diffractometer) using a $\mathrm{Cu} K_{\alpha}$ radiation at $\lambda=1.54060 \AA$ operating at a voltage of $30 \mathrm{kV}$ and a current of $10 \mathrm{~mA}$ at a $2 \theta$ range for $10-90^{\circ}$ with a sweeping rate of $2^{\circ} / \mathrm{min}$. FTIR-4700 JASCO with ATR was used to study the presence of the metal oxide bonds in the samples. It was also used to check the presence of other impurities as well as the vibrating frequencies in the sample. It was operating at a range of $350-4000 \mathrm{~cm}^{-1}$. Morphologies of the synthesized ferrite were determined using a Zeiss DSM 982 Gemini field emission scanning electron microscope (FE-SEM), with a Schottky emitter at accelerating voltage of $10 \mathrm{kV}$ with a beam current of 1.0 mA. HR-TEM micrographs were obtained using JEOL JEM-2100 highresolution electron microscope. Elemental analysis was done using S1TITAN BRUKER x-ray fluorescence spectroscopy (XRF).

\section{RESULTS AND DISCUSSIONS}

\subsection{Structural Studies}

X-ray spectra of $\mathrm{Cu}_{x} \mathrm{Mg}_{1-x} \mathrm{NiFe}_{2} \mathrm{O}_{4}$ for $x=0,0.15,0.3,0.45,0.6,0.75$, and 1 are shown Fig. 1.

The peaks show characteristic of cubic spinel phase. The sharp peaks 


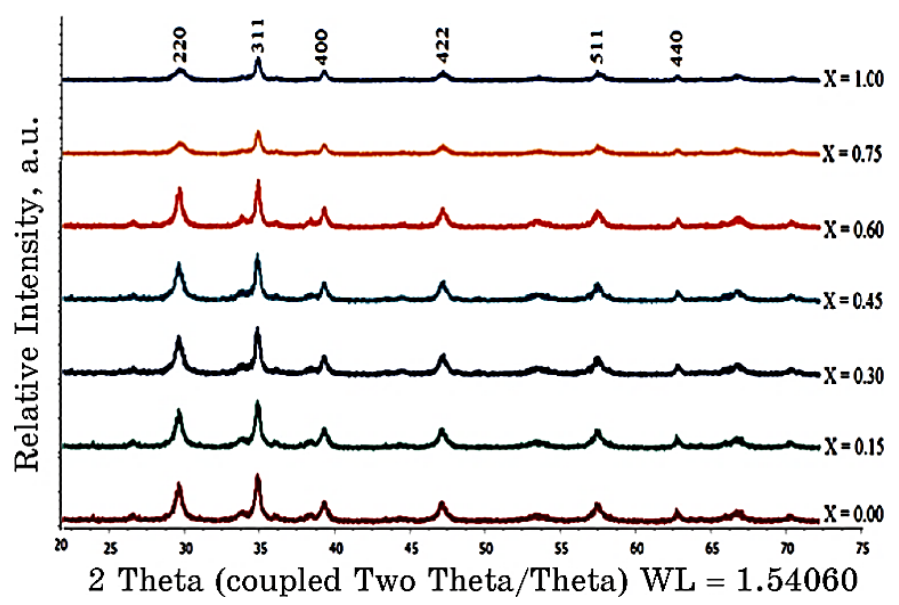

Fig. 1. XRD defractographs of $\mathrm{Cu}_{x} \mathrm{Mg}_{1-x} \mathrm{NiFe}_{2} \mathrm{O}_{4}$ for $x=0.00,0.15,0.30,0.45$, $0.60,0.75$, and 1.00 for ferrite nanoparticles synthesized at $\mathrm{pH} 7$, calcined at $700^{\circ} \mathrm{C}$. The most intense peak is at Miller index (311).

signify crystalline nature of the copper-magnesium-nickel ferrite nanoparticles [3, 17].

Peaks were located at $2 \theta^{\circ}=30^{\circ}, 35^{\circ}, 37^{\circ}, 43^{\circ}, 57^{\circ}$ and $62^{\circ}$, for the Miller indices (220), (311), (400), (422), (511) and (440), respectively. The highest reflection peak appears at $35^{\circ}$ that corresponds to Miller index (311) and indicates that nanocrystalline ferrite samples were synthesized. The sharp peaks signify high degree of crystallization and fine particle formation $[18,19]$. Particles show some noise in the background, which is a characteristic of nanoparticles [20]. The particle size was calculated from the Scherrer's formula,

$$
D=0.9 \lambda /(\beta \cos \theta),
$$

where $D$ is the crystalline size; $\lambda$ - the x-ray wavelength; $\beta$ is the angular line width at half-maximum intensity, given by $\beta=0.5 \pi F W H M$, and $\theta$-the Bragg's angle [21]. The particle size was found to be between 4.1-35.58 nm. The small size can be attributed to the stoichiometry of the cation. In a mixed spinel ferrite like $\mathrm{Cu}_{x} \mathrm{Mg}_{1-x} \mathrm{NiFe}_{2} \mathrm{O}_{4}$, a number of cations are integrated in the structure. In regard to this, growth and nucleation of nanoparticles can be affected by capability, probability and affinity of cations to occupy the available sites [22]. The concentration with smallest nanoparticles was found to be $x=0.15$, as it recorded the highest intense peak. The lattice parameter, $a$, for the samples was calculated using the relation:

$$
a=d \sqrt{h^{2}+k^{2}+l^{2}},
$$


where $h, k$ and $l$ are the Miller indices from the most intense peaks [23]. The relationship between particle size, lattice parameter and sample concentration are shown in Fig. 2 and Table 1.

The lattice parameters increase with increase in concentration up to the ratio $x=0.15$, then decreases for the ratio $x=0.43$ and finally remains constant for the other ratios. This variation may be attributed to the difference in ionic radius between $\mathrm{Cu}^{2+}(0.73 \AA)$ and $\mathrm{Mg}^{2+}(0.72 \AA)$, where copper ions migrate to $B$ sites while magnesium migrate to $A$ sites [24]. For the particle size, samples with ratios $(x=0, x=0.15$ and $x=0.75$ ) obey the Vegard's rule whereby there is an increase in particle size as doping is done. This is brought about by the both the chelating agent and the sintering temperature. On the other hand, samples with ratios $(x=0.30, x=0.45, x=0.60$ and $x=1.00)$ also show little variations in the particle size with copper content. This clearly confirms

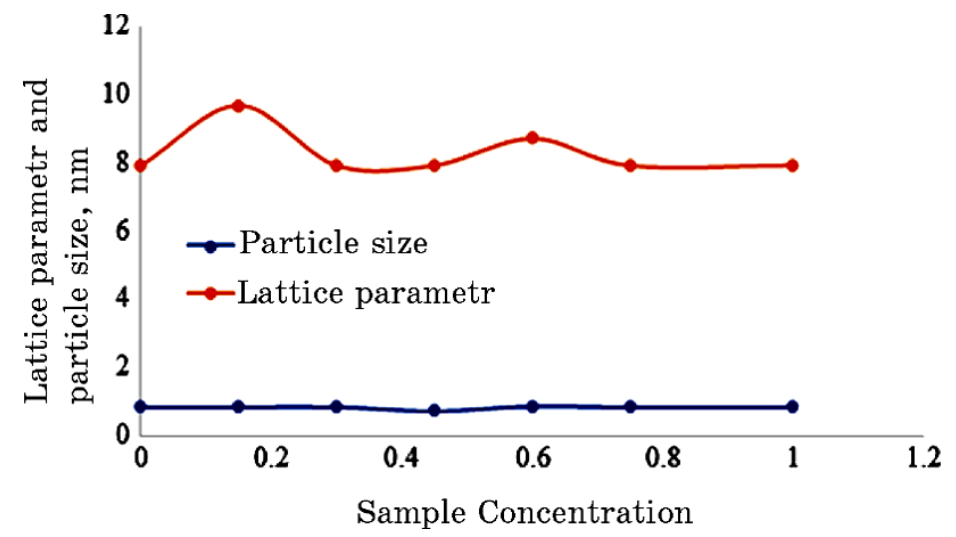

Fig. 2. A graph of particle size and lattice parameter against concentration of $\mathrm{Cu}_{x} \mathrm{Mg}_{1-x} \mathrm{NiFe}_{2} \mathrm{O}_{4}$ for $x=0.00,0.15,0.30,0.45,0.60,0.75$, and 1.00 ferrite nanoparticles, synthesized at $\mathrm{pH} 7$, calcined at $700^{\circ} \mathrm{C}$. It shows that copper doping varies the lattice parameters as well as the particle size.

TABLE 1. Relationship between sample concentration, $d$-spacing, lattice parameter and particle size of $\mathrm{Cu}_{x} \mathrm{Mg}_{1-x} \mathrm{NiFe}_{2} \mathrm{O}_{4}$ ferrite nanoparticles.

\begin{tabular}{c|cccc}
\hline Concentration & $d$-spacing & Lattice parameter, $\mathrm{nm}$ & Particle size, $\mathrm{nm}$ \\
\hline$X=0$ & 0.252 & 0.8357 & 7.92 \\
$X=0.15$ & 0.252 & 0.8357 & 9.68 \\
$X=0.3$ & 0.254 & 0.8424 & 7.91 \\
$X=0.45$ & 0.256 & 0.7240 & 7.92 \\
$X=0.6$ & 0.252 & 0.8667 & 8.71 \\
$X=0.75$ & 0.252 & 0.8337 & 7.91 \\
$X=1$ & 0.252 & 0.8358 & 7.92 \\
\hline
\end{tabular}


that copper doping changes the structure of the ferrite.

Figure 3 shows FTIR spectral graphs with peaks between 400-499 $\mathrm{cm}^{-1}$, which are assigned metal-oxygen vibrations in octahedral sites
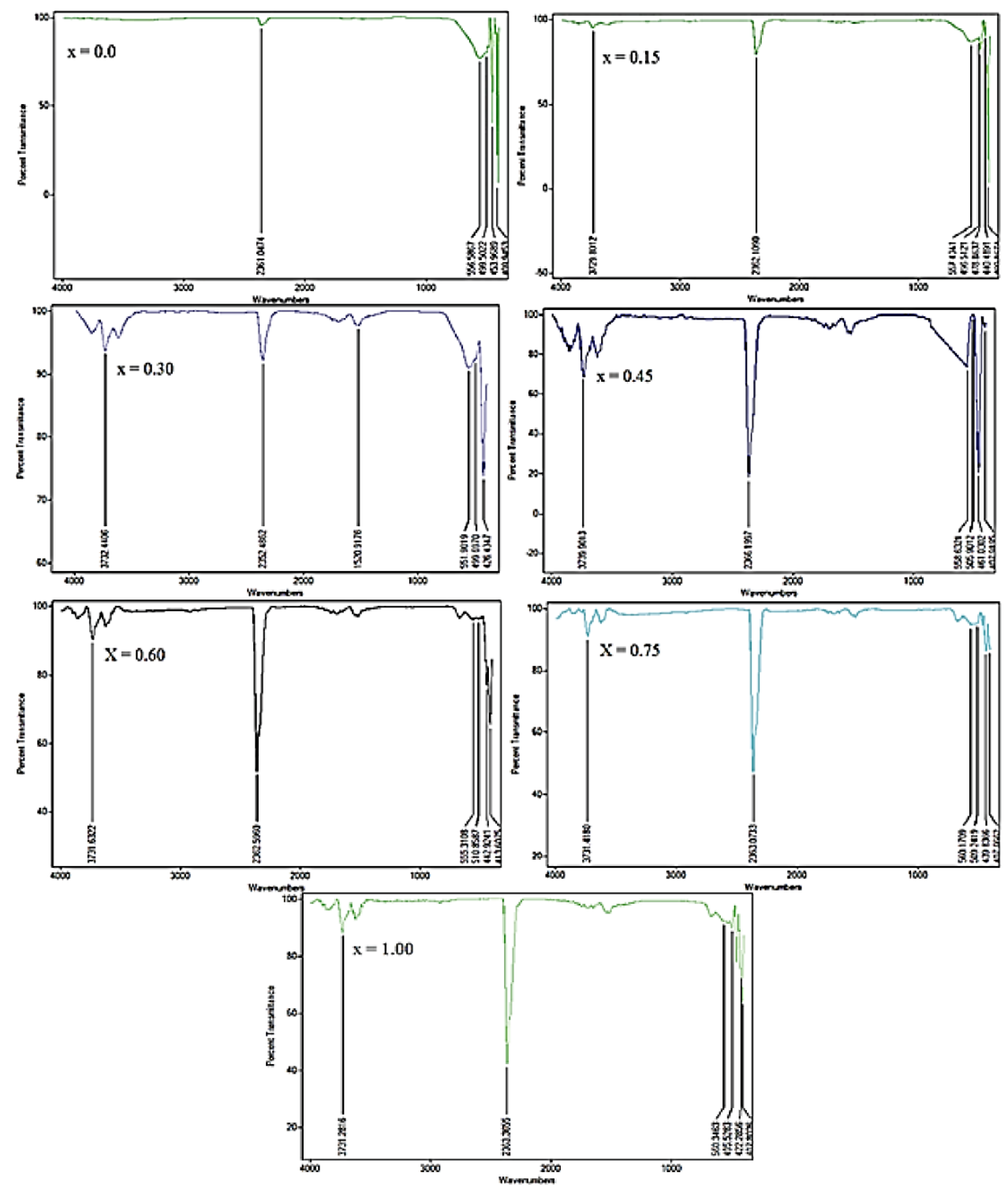

Fig. 3. FTIR spectrum of $\mathrm{Cu}_{x} \mathrm{Mg}_{1-x} \mathrm{NiFe}_{2} \mathrm{O}_{4}$ for $x=0.00,0.15,0.30,0.45,0.60$, 0.75 , and 1.00 , respectively, synthesized at $\mathrm{pH} 7$, calcined at $700^{\circ} \mathrm{C}$. They show octahedral and tetrahedral bonds between $400-600 \mathrm{~cm}^{-1}$ as characteristic of spinel ferrites nanoparticles. 
and $500-600 \mathrm{~cm}^{-1}$, which are attributed to metal-oxygen vibrations in the tetrahedral sites [25].

In Figure 3, the sample with ratio $x=0.00$ shows two octahedral metal-oxygen vibrational bonds observed between $409-499 \mathrm{~cm}^{-1}$, and tetrahedral vibration is observed at $556 \mathrm{~cm}^{-1}$. In $x=0.15$, we observe an increased vibration with octahedral one between $400-496 \mathrm{~cm}^{-1}$ and tetrahedral one at $557 \mathrm{~cm}^{-1}$ as effect of copper doping on the structure of ferrite nanoparticle. For $x=0.30$, octahedral vibrations are observed between wave number $426-499 \mathrm{~cm}^{-1}$ and tetrahedral ones at $551 \mathrm{~cm}^{-1}$, while in $x=0.45$, octahedral ones are observed between $407-465 \mathrm{~cm}^{-1}$, and tetrahedral ones are between $505-558 \mathrm{~cm}^{-1}$ an effect of copper doping. In $x=0.60$, we observe octahedral vibrations between $413-442 \mathrm{~cm}^{-1}$ and tetrahedral ones between $510-555 \mathrm{~cm}^{-1}$. In $x=0.75$, octahedral ones are observed between $407-439 \mathrm{~cm}^{-1}$ and tetrahedral ones between 509$560 \mathrm{~cm}^{-1}$ and, finally, in $x=1.00$, we observe octahedral ones between $407-495 \mathrm{~cm}^{-1}$ and tetrahedral ones at $560 \mathrm{~cm}^{-1}$.

The peaks at wave numbers $400-499 \mathrm{~cm}^{-1}$ are accredited to metaloxygen vibrations octahedral metal complex, with bonds between oxygen ions and the octahedral sites ion due to bending vibrations. The peaks at wave numbers $500-600 \mathrm{~cm}^{-1}$, which are assigned to metaloxygen vibrations in the tetrahedral sites due to stretching vibrations [21]. These characteristic vibrations are caused by copper migration to octahedral sites while magnesium to tetrahedral site [25]. This difference in bands, lower at $\left(400-499 \mathrm{~cm}^{-1}\right)$ and higher at $\left(500-600 \mathrm{~cm}^{-1}\right)$ is caused by the dimensions of octahedral being lager than that of tetrahedral. Further, the intensity of the band is caused by the fraction change in dipole moment with inter nuclear distance [26]. The wave numbers $3729-3739 \mathrm{~cm}^{-1}$ are ascribed to $\mathrm{OH}$ stretch while $2352-2366 \mathrm{~cm}^{-1}$ are due to $\mathrm{CO}_{2}$ absorbed in the air. Other bands being weak shows that doping was successfully done [27]. The characteristic vibrations observed are caused by copper migration to octahedral sites while magnesium to tetrahedral site [28]. This difference in bands is caused by the dimensions of octahedral sites being higher than that of tetrahedral ones. Further, the intensity of the band is caused by the fraction change in dipole moment with inter nuclear distance [27]. The wave numbers 3729-3739 $\mathrm{cm}^{-1}$ are ascribed to $\mathrm{OH}$ stretch while $2352-2366 \mathrm{~cm}^{-1}$ are due to $\mathrm{CO}_{2}$ absorbed in the air [28]. Other bands being weak shows that doping was successfully done [26].

\subsection{Morphological Studies}

The micrographs of high-resolution transmission electron microscope are presented in Fig. 4.

The images show presence of dark and bright regions on the micrographs, which are due to high and low concentration of the samples re- 


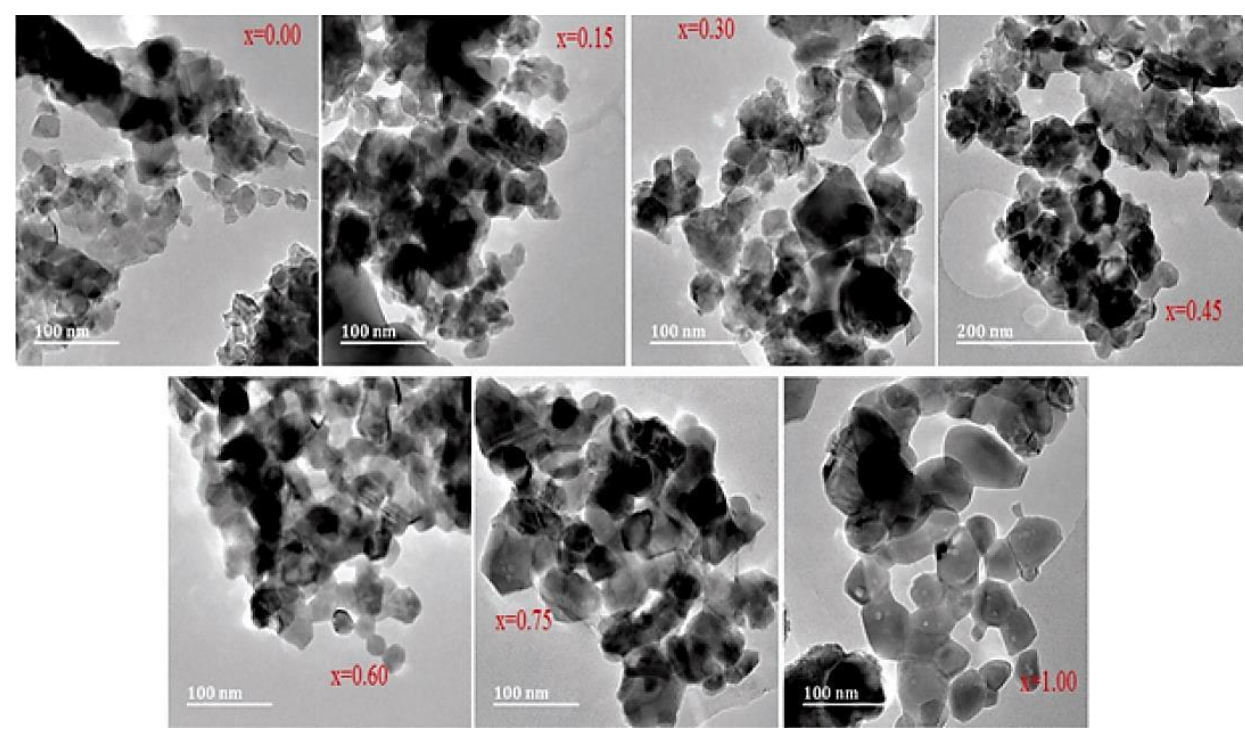

Fig. 4. HRTEM images $\mathrm{Cu}_{x} \mathrm{Mg}_{1-x} \mathrm{NiFe}_{2} \mathrm{O}_{4}$ for $x=0.00,0.15,0.30,0.45,0.60$, 0.75 , and 1.00 for ferrite nanoparticles synthesized at $\mathrm{pH} 7$, calcined at $700^{\circ} \mathrm{C}$. They show particle distribution and morphology. The particle size is in the range of $16-45 \mathrm{~nm}$.

spectively [25]. The copper-doped magnesium-nickel ferrite nanoparticles show spherical shaped particles a characteristic of spinel ferrites. The size of the particles is between $16-45 \mathrm{~nm}$ as determined by ImageJ software, which confirms formation of nanoparticles. The samples also are seen to cluster or agglomerate, which shows a good sign of interparticle separation [30]. Clustering of the nanoparticles is attributed to addition of ammonia solution, which causes nucleation and grain growth in short duration [31].

Further, the microstructures of the samples as determined by the scanning electron microscopy are presented in Fig. 5.

From the images in Fig. 5, it is evident that doping brings about changes in the microstructure of the synthesized samples. This is seen from different distribution of the particles for different ratios [10]. Some micrographs show spherical shaped nanoparticles $(x=0, x=0.15$ and $x=0.3)$, which agrees with HRTEM [28], while samples $(x=0.45$, $x=0.6, x=0.75$ and $x=1$ ) depicts angular morphology [32]. The SEM images reveals properties associated with cubic spinel structured synthesized samples [3]. Copper doping increases particle separation.as seen from the images.

Clustering of particles is noted in all the micrographs as such particles experience permanent magnetic moments. High calcination temperatures can also affect particle formation [31]. This agrees with TEM 


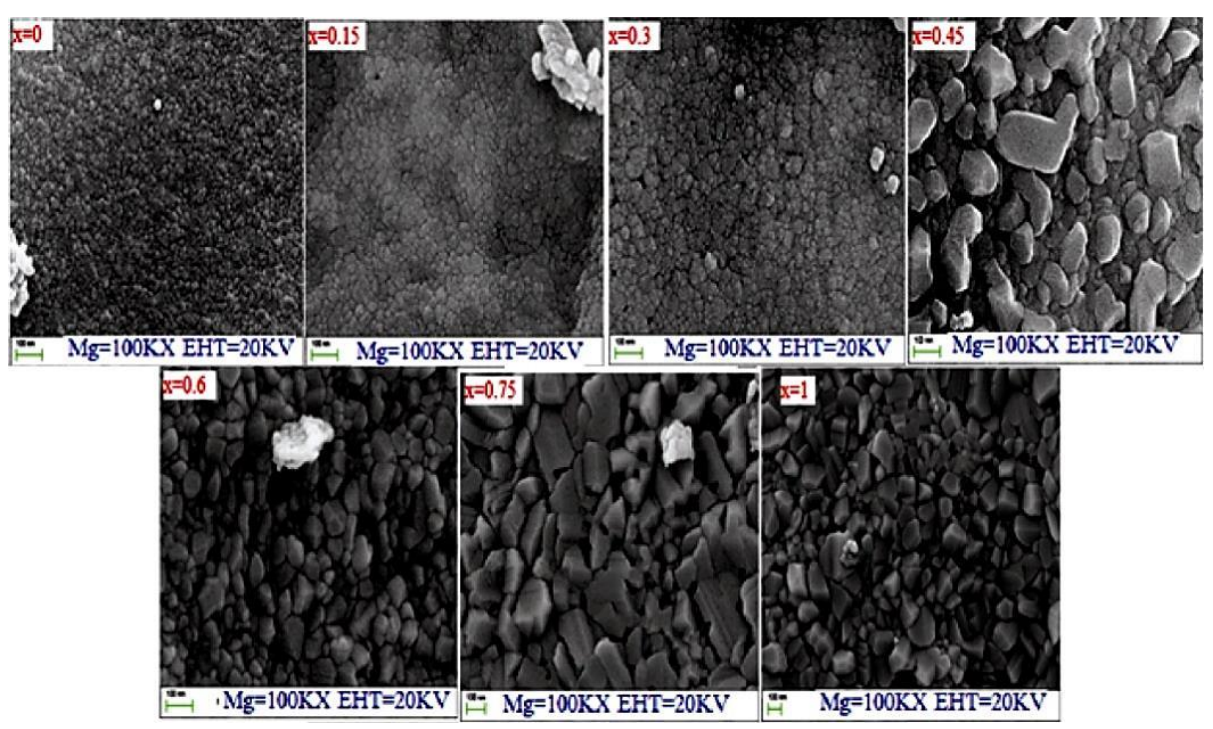

Fig. 5. SEM images $\mathrm{Cu}_{x} \mathrm{Mg}_{1-x} \mathrm{NiFe}_{2} \mathrm{O}_{4}$ for $x=0.00,0.15,0.30,0.45,0.60,0.75$ and 1.00 for ferrite nanoparticles synthesized at $\mathrm{pH} 7$, calcined at $700^{\circ} \mathrm{C}$. They show particle distribution and morphologies. Samples with $x=0.45-1$ clearly show particle separation an effect of doping.

analysis.

Further, there is evidence of some formation of plate-like shaped particles that indicates crystalline nature of particles [27]. It is worth noting that particles at nanoscale possess high surface energy hence they tend to agglomerate [33].

\subsection{Elemental Analysis}

The x-ray fluorescence elemental composition of the samples is as shown in Table 2. The percentage composition of the copper-doped magnesium-nickel ferrite is as expected. Though there are traces of impurities in the sample, the synthesis process of the nanoparticle was a success [26]. The XRF that is a semi-quantitative chemical analysis and showed that the synthesized samples have low level of impurities and do not have heavy metal contamination.

\section{CONCLUSION}

Nanotechnology is the art of manipulating matter in nanometer scale. This knowledge helps in coming up with materials for fabrication of electronic devices. In this study, copper-doped magnesium-nickel fer- 
TABLE 2. Elemental composition of $\mathrm{Cu}_{x} \mathrm{Mg}_{1-x} \mathrm{NiFe}_{2} \mathrm{O}_{4}$ for $x=0.00,0.15,0.30$, $0.45,0.60,0.75$, and 1.00 ferrites nanoparticles.

\begin{tabular}{c|c|c|c|c|c|c|c}
\hline Sample & $x=0$ & $x=0.15$ & $x=0.3$ & $x=0.45$ & $x=0.6$ & $x=0.75$ & $x=1$ \\
\hline $\mathrm{Mg}$ & 11.710 & 4.810 & 3.149 & 1.926 & 1.445 & 5.265 & - \\
$\mathrm{Ni}$ & 67.671 & 58.121 & 53.342 & 43.100 & 43.516 & 56.838 & 44.509 \\
$\mathrm{Cu}$ & 0.691 & 20.444 & 28.803 & 43.100 & 43.516 & 21.99 & 44.509 \\
$\mathrm{Fe}$ & 17.099 & 14.352 & 12.571 & 10.096 & 9.806 & 13.847 & 9.246 \\
Impurities & 2.829 & 2.273 & 2.135 & 1.778 & 1.717 & 2.068 & 1.736 \\
\% total & 100 & 100 & 100 & 100 & 100 & 100 & 100 \\
\hline
\end{tabular}

rite was successfully synthesized thorough Citra gel autocombustion method. The focus of the analysis was structural elucidation using XRD and FTIR, morphological using SEM and TEM and elemental analysis using XRF. In XRD analysis, the samples showed cubic spinel characteristic with intense peaks at Miller indices (311). The size of the particles was $4.1-35.58 \mathrm{~nm}$. The lattice constant was in the range $0.7240-0.8667$ $\mathrm{nm}$. FTIR analysis indicated frequencies between $400-499 \mathrm{~cm}^{-1}$ and $500-600 \mathrm{~cm}^{-1}$, which are indicators of vibrations in octahedral and tetrahedral sites, respectively. From SEM and TEM, the samples showed spherical nature with presence of dark and bright regions. The size from TEM was in the range of 16-45 $\mathrm{nm}$. SEM indicated angular morphology of the particles. XRF showed the expected stoichiometry of the samples. It is concluded that samples with $x=0.15$ and $x=0.30$ had the smallest crystal size, which can be applied in memory and electronic storage devices [2]. They can also find application in high-density recording media as they can help in attaining a desirable signal-to-noise ratio.

\section{ACKNOWLEDGEMENT}

The authors acknowledge Chuka University, University of Kwa Zulu Natal and United States International University (USIU).

\section{REFERENCES}

1. I. Khan, K. Saeed, and I. Khan, Arabian Journal of Chemistry, 12, No. 7: 908 (2019); https://doi.org/10.1016/j.arabjc.2017.05.011

2. C. Venkataraju, G. Sathishkumar, and K. Sivakumar, Journal of Magnetism and Magnetic Materials, 322, Iss. 2: 230 (2010); https://doi.org/10.1016/j.jmmm.2009.08.043

3. R. M. Rosnan, Z. Othaman, R. Hussin, A. A. Ati, A. Samavati, S. Dabagh, and 
S. Zare, Chinese Physics B, 25, No. 4: 047501 (2016);

https://doi.org/10.1088/1674-1056/25/4/047501

4. Y. K. Dasan, B. H. Guan, M. H. Zahari, and L. K. Chuan, PloS One, 12, No. 1: e0170075 (2017); doi: 10.1371/journal.pone.0170075

5. J. Jacob and M. A. Khadar, Journal of Applied Physics, 107, Iss. 11: 114310 (2010); https://doi.org/10.1063/1.3429202

6. X. Zuo, A. Yang, C. Vittoria, and V. G. Harris, Journal of Applied Physics, 99, Iss. 8: 08M909 (2006); https://doi.org/10.1063/1.2170048

7. P. P. Hankare, V. T. Vader, N. M. Patil, S. D. Jadhav, U. B. Sankpal, M. R. Kadam, and N. S. Gajbhiye, Materials Chemistry and Physics, 113, Iss. 1: 233 (2009); https://doi.org/10.1016/j.matchemphys.2008.07.066

8. T. Smitha, X. Sheena, P. J. Binu, and E. M. Mohammed, IOP Conference Series: Materials Science and Engineering, 73, No.1: 012094 (2015); https://doi.org/10.1088/1757-899X/73/1/012094

9. S. Y. Mulushoa, N. Murali, M. T. Wegayehu, S. J. Margarette, and K. Samatha, Results in Physics, 8: 772 (2018); https://doi.org/10.1016/j.rinp.2017.12.062

10. A. I. Ahmed, M. A. Siddig, A. A. Mirghni, M. I. Omer, and A. A. Elbadawi, Advances in Nanoparticles, 4, No. 2: 45 (2015); doi: 10.4236/anp.2015.42006

11. A. E. A. A. Said, M. M. A. El-Wahab, S. A. Soliman, and M. N. Goda, Nanoscience and Nanoengineering, 2, No.1: 17 (2014); doi:10.13189/nn.2014.020103

12. F. S. Tehrani, V. Daadmehr, A. T. Rezakhani, R. H. Akbarnejad, and S. Gholipour, Journal of Superconductivity and Novel Magnetism, 25, No. 7: 2443 (2012); https://doi.org/10.1007/s10948-012-1655-5

13. D. Cao, L. Pan, J. Li, X. Cheng, Z. Zhao, J. Xu, Q. Li, X. Wang, S. Li, J. Wang, and Q. Liu, Scientific Reports, 8, No. 1: 8989 (2018); https://doi.org/10.1038/s41598-018-26341-4

14. K. K. Kefeni, T. A. Msagati, and B. B. Mamba, Materials Science and Engineering: $B$, 215: 37 (2017); https://doi.org/10.1016/j.mseb.2016.11.002

15. A. Sutka and G. Mezinskis, Frontiers of Materials Science, 6, No. 2: 128 (2012); https://doi.org/10.1007/s11706-012-0167-3

16. S. Zahi, A. R. Daud, and M. Hashim, Materials Chemistry and Physics, 106, Iss. 2-3: 452 (2007); https://doi.org/10.1016/j.matchemphys.2007.06.031

17. T. Shanmugavel, S. Gokul Raj, G. Ramesh Kumar, and G. Rajarajan, Physics Procedia, 54: 159 (2014); https://doi.org/10.1016/j.phpro.2014.10.053

18. J. Azadmanjiri, H. K. Salehani, M. R. Barati, and F. Farzan, Materials Letters, 61, Iss. 1: 84 (2007); https://doi.org/10.1016/j.matlet.2006.04.011

19. Z. K. Heiba, M. B. Mohamed, A. M. Wahba, and L. Arda, Journal of Superconductivity and Novel Magnetism, 28, No. 8: 2517 (2015); https://doi.org/10.1007/s10948-015-3069-7

20. T. K. Pathak, N. H. Vasoya, V. K. Lakhani and K. B. Modi, Ceramics International, 36, Iss. 1: 275 (2010); https://doi.org/10.1016/j.ceramint.2009.07.023

21. S. Thankachan, B. P. Jacob, S. Xavier, and E. M. Mohammed, Physica Scripta, 87, No. 2: 025701 (2013); https://doi.org/10.1088/0031-8949/87/02/025701

22. A. Maqsood and A. Faraz, Journal of Superconductivity and Novel Magnetism, 25, No. 5: 1025 (2012); https://doi.org/10.1007/s10948-011-1343-x

23. V. Jeseentharani, M. George, B. Jeyaraj, A. Dayalan, and K. S. Nagaraja, Journal of Experimental Nanoscience, 8, Iss. 3: 358 (2013); https://doi.org/10.1080/17458080.2012.690893 
24. R. Sridhar, D. Ravinder, and K. V. Kumar, Advances in Materials Physics and Chemistry, 2, No. 3: 192 (2012); doi: 10.4236/ampc.2012.23029

25. J. Balavijayalakshmi and M. J. Saranya, NanoSci. NanoTechno, 2, Iss. 4: 397 (2014).

26. D. Mott, J. Galkowski, L. Wang, J. Luo, and C. J. Zhong, Langmuir, 23, No. 10: 5740 (2007); https://doi.org/10.1021/la0635092

27. M. Maria Lumina Sonia, S. Blessi, and S. Pauline, International Journal of Research, 1, No. 8, Pt. 3: 70 (2014).

28. C. Venkataraju, G. Sathishkumar, and K. Sivakumar, Journal of Magnetism and Magnetic Materials, 322, Iss. 2: 230 (2010); https://doi.org/10.1016/j.jmmm.2009.08.043

29. L. Khanna and S. K. Tripathi, Research Journal of Recent Sciences, 6, Iss. 2: 1 (2017); Microsoft Word - 1.ISCA-RJRS-2017-002.docx

30. A. Gaber, M. A. Abdel-Rahim, A. Y. Abdel-Latief, and M. N. Abdel-Salam, Int . J.Electrochem.Sci., 9: 81 (2014); 90100081.pdf (electrochemsci.org)

31. N. Sanpo, C. Wen, C. C. Berndtn, and J. Wang, Microbial Pathogens and Strategies for Combating Them: Science, Technology and Education (Spain: Formatex Research Centre: 2013), vol. 1, p. 239.

32. H. Arabi and N. Khalili Moghadam, Journal of Magnetism and Magnetic Materials, 335: 144 (2013); https://doi.org/10.1016/j.jmmm.2013.02.006

33. S. Sagadevan, Z. Z. Chowdhury, and R. F. Rafique, Materials Research, 21, No. 2: e20160533 (2018); https://doi.org/10.1590/1980-5373-mr-2016-0533 